\title{
Intramuscular fatty acid composition of steers finished on oat pastures mixture with vetch or cornmeal supplementation
}

\author{
Talita Cristina Taffarel ${ }^{1}$ Luís Fernando Glasenapp de Menezes ${ }^{{ }^{*}}$ (iD Fernando Kuss ${ }^{1}$ \\ Wagner Paris ${ }^{1}$ José Laerte Nörnberg $^{2}$ Roberta Farenzena ${ }^{1}$ \\ Eduardo Felipe Colerauz De Oliveira Lazzarotto ${ }^{1}$ Matheus Massaru Goto Hirai ${ }^{1}$
}

${ }^{1}$ Universidade Tecnológica Federal do Paraná (UTFPR), 85660-000, Dois Vizinhos, PR. Brasil. E-mail: luismenezes@utfpr.edu.br. ${ }^{*}$ Corresponding author.

${ }^{2}$ Universidade Federal de Santa Maria (UFSM), Santa Maria, RS, Brasil.

ABSTRACT: The effects of energetic supplementation and mixture vetch (Vica sativa L.) were studied to evaluate the intramuscular fatty acid profile of steers finished on oat (Avena sativa L.) pastures. Eighteen 21-month-old crossbred steers were evaluated. The experiment was carried out in three treatments and six repetitions: oat pasture $(O A)$, oat pasture + vetch $(O A+V E T)$, and oat pasture + supplementation $(O A+S U P)$. Supplementation comprised the addition of corn meal at a daily dose of $1 \%$ of the animals'body weight. Steers receiving supplementation had higher lipid content in Longissimus lumborum than did those fed with OA +VET (1.25 vs 1.02\%), whereas those fed with OA (1.15\%) showed intermediate values. Conjugated linoleic acid levels were higher in steers fed OA (0.57\%) and OA $+S U P(0.59 \%)$, whereas the highest amount of omega-3 fatty acids was observed in animals fed OA + VET (3.32\%). Pasture-finishing without supplementation resulted in a lower ratio of n-6:n-3 (3.14). Steers finished in oat mixture with vetch showed healthier intramuscular fat than did those finished with cornmeal supplementation; importantly, the higher the amount of PUFAs, the better n-6:n-3 ratio.

Key words: conjugated linoleic acid, energetic supplementation, grass, legume.

Composição de ácidos graxos da gordura intramuscular de novilhos terminados em pastagem de aveia consorciada com ervilhaca ou suplementados com grão de milho moído

RESUMO: Os efeitos da suplementação energética e da ervilhaca (Vica sativa L.) foram estudados para avaliar o perfil de ácidos graxos intramusculares de novilhos terminados em pastagens de aveia (Avena sativa L.). Foram avaliados 18 novilhos mestiços com 21 meses de idade. O experimento foi realizado em três tratamentos e seis repetições: pastagem de aveia (OA), pastagem de aveia + ervilhaca (OA + $V E T)$ e pastagem de aveia + suplementação $(O A+S U P)$. A suplementação compreendeu a adição de fubá na dose diária de $1 \%$ do peso corporal dos animais. Os novilhos que receberam suplementação apresentaram maior teor lipídico no Longissimus lombar do que aqueles alimentados com OA + VET (1,25 contra 1,02\%), enquanto aqueles alimentados com AO (1,15\%) apresentaram valores intermediários. Os níveis de ácido linoléico conjugado foram maiores em novilhos alimentados com AO (0,57\%) e OA + SUP (0,59\%), enquanto a maior quantidade de ácidos graxos ômega-3 foi observada em animais alimentados com $O A+V E T$ (3,32\%). Animais terminados em pastagens sem suplementação apresentaram menor proporção de n-6: $n-3(3,14)$. Novilhos terminados em pastagem de aveia com ervilhaca apresentaram gordura intramuscular mais saudável do que aqueles terminados com suplementação de milho moído, uma vez que apresentaram maior quantidade de PUFAs e melhor a relação n-6: $n$-3.

Palavras-chave: ácido linoleico conjugado, gramíneas, leguminosas, suplementação energética.

\section{INTRODUCTION}

Mixture between grasses and temperate legumes has proved to be important for feeding beef cattle because these species possess excellent forage quality and provide high yields per area, allowing for long grazing periods, and improving the performance of animals during the critical production period (LISBINSKI et al, 2019). This increase in production is because of the long and later cycle of legume as compared to oat (WAGHORN $\&$ CLARK, 2004). Oats have low dry matter content, which may cause physical limitation of the rumen (VAN
SOEST, 1994). Furthermore, energy supplementation is an alternative often used for finishing cattle in temperate pasture because these supplement assist in nutrient balance and increase the total dry matter intake (MOORE et al., 1999).

The beef cattle production aiming for high meat quality depends on the nutritional value of the diet offered to the animals. Factors that influenced the quality of animal products can be controlled at various stages of their production through manipulation of parameters such as nutrition that directly affect the growth rate of animals (WOOD et al, 2003). 
Studies have shown that increased inclusion of forage in the diet is advantageous to the animals' fat composition, and cattle finished on pastures have lower omega-6/omega-3 ratio and higher amounts of conjugated linoleic acid (CLA), both of which are beneficial to human health (VARELA et al, 2004.). According to VARELA et al. (2004) the polyunsaturated omega-6/omega-3 ratio is an index of the role of fatty acids in human arteriosclerosis. Fatty acids of the omega- 3 series tend to decrease the levels of arachidonic acid in the tissues, inhibiting cyclogenase and lipogenase activities, with effect antithrombotic, reducing lipid levels in the plasma and increasing prostaglandin synthesis. According to MULVIHILL (2001), in animal studies, CLA reduced the risk of breast tumors and inhibited the induction of skin tumors and, because it has immuno-mediating antiteratogenic properties, increases growth efficiency, reduced body fat and prevents diabetes. Grain diets decrease ruminal biohydrogenation rate by the growth of microorganisms (GARCIA et al, 2008).

Recent research has focused on beef cattle fed with a temperate pasture mixture of legumes. However, there is a scarcity of literature discussing the effects of mixture pastures in temperature climates with legumes on the composition and profile of fatty acids in the meat of cattle in the finishing stage. Against this background, the present study investigated the effects of energetic supplementation and mixture vetch (Vicia sativa L.) to evaluate the intramuscular fatty acid profiles of steers finished on oat (Avena sativa L.) pastures.

\section{MATERIALS AND METHODS}

Eighteen castrated steers (crossbred 1/4 Marchigiana, 1/4 Aberdeen Angus, 1/2 Nellore) at 19 \pm 1.2 months of age and a mean initial body weight of $360 \pm 34.3 \mathrm{~kg}$, were evaluated. Seven hectares, subdivided into nine paddocks of 0.78 ha each, were used for the study, ( 3 paddocks each treatment and 2 steers each paddock). Animals (6 per treatment) were assigned to the following treatments: oat pasture $(\mathrm{OA})$, oat pasture + vetch $(\mathrm{OA}+\mathrm{VET})$, and oat pasture + supplementation with corn meal at $1 \%$ of the body weight per day, based on dry matter (OA + SUP).

A continuous grazing system with variable stocking rate was adopted by following the methodology described by MOTT \& LUCAS (1952). The forage mass was evaluated based on the visual estimation technique described by CAMPBELL \& ARNOLD (1973). Average forage mass (893 $\mathrm{kg} \mathrm{DM} / \mathrm{ha})$, stocking rate $(1360.5 \mathrm{~kg}$ live weight (LW)/ha) and herbage allowance $(7.1 \mathrm{~kg} \mathrm{DM} / 100$ $\mathrm{kg}$ LW) showed no difference between treatments (HIRAI et al., 2015). More information on pasture implementation and pasture management were as described by HIRAI et al. (2015).

All the animals were slaughtered at the end of the grazing cycle (75 grazing days). The animals were transported by truck on a paved road about $30 \mathrm{~km}$ away to commercial 1 abattoir, with state inspection, where they were slaughtered following the conventional practices of the Brazilian beef industry. They were weighed after $12 \mathrm{~h}$ of fasting. On average, the final body weight of steers was $413 \pm 5.2 \mathrm{~kg}$ with $2.4 \pm 0.3 \mathrm{~mm}$ fat thickness values. Carcass and meat characteristic of the animals are presented by Hirai et al. (2014).

The carcasses were identified and weighed before cooling at $4{ }^{\circ} \mathrm{C}$ for $24 \mathrm{~h}$. After cooling, the right half of the carcass was used to determine the quantitative traits. Twenty-four hours later, longissimus lumborum samples were obtained by a complete cross-section between the $11^{\text {th }}$ and $13^{\text {th }}$ ribs. The fat layer was discarded and the muscle portion was vacuum packaged, identified, frozen in the freezing tunnel $\left(-30{ }^{\circ} \mathrm{C}\right.$ to $\left.-35^{\circ} \mathrm{C}\right)$, and maintained in a freezer at $-20{ }^{\circ} \mathrm{C}$ until further analysis (storage $=90$ days).

At the laboratory, the samples of foods (Table 1) and meat were subjected to extraction and methylation analyses, quantitative determination of the lipid fraction, and qualitative determination of fatty acids. The beef was ground in a food processor with dry ice to prevent heating and possible chemical changes. The fraction of total lipids was extracted from the samples according to the methodology of BLIGH \& DYER (1959). Fatty acids were esterified according to the technique described by HARTMAN \& LAKE (1973) and analyzed using a gas chromatograph, Agilent brand (model HP6890), equipped with a flame ionization detector (FID) and Supelco SP2560 capillary column (100m x $0.25 \mathrm{~mm}$ $\mathrm{x} 0.2 \mu \mathrm{m})$. Injector and detector temperatures were maintained at $250{ }^{\circ} \mathrm{C}$ and $280{ }^{\circ} \mathrm{C}$, respectively. Temperature gradient used to separate the fatty acid esters was $140{ }^{\circ} \mathrm{C}$ for $5 \mathrm{~min}$., increasing $1.6{ }^{\circ} \mathrm{C} / \mathrm{min}$ to $210^{\circ} \mathrm{C}$, maintained for $10 \mathrm{~min}$; increasing $10{ }^{\circ} \mathrm{C} /$ min to $240{ }^{\circ} \mathrm{C}$, maintained for a further 15 minutes, totaling a 76-minute run. The carrier gas flow rate (N2) was $30 \mathrm{~mL} / \mathrm{min}$. The injection volume was $1 \mu \mathrm{L}$ with a split ratio of 1:50. The fatty acids were identified by comparing the retention time of the fatty acids from the samples with known standards. 
Table 1 - Fatty acids profile (percentage of fatty acids) of the experimental diets of oats and vetch pastures and corn meal.

\begin{tabular}{|c|c|c|c|}
\hline \multirow[t]{2}{*}{ Fatty acid } & \multicolumn{3}{|c|}{-----------------------------------------Food---------------------------------' } \\
\hline & Oat & Vetch & Cornmeal \\
\hline $\mathrm{C} 12: 0$ & 1.79 & 0.47 & 0.06 \\
\hline $\mathrm{C} 14: 0$ & 1.19 & 0.86 & 0.16 \\
\hline $\mathrm{C} 15: 0$ & 0.61 & 0.27 & 0.04 \\
\hline C16:0 & 19.74 & 16.81 & 13.47 \\
\hline $\mathrm{C} 17: 0$ & 0.75 & 0.51 & 0.10 \\
\hline C18:0 & 2.68 & 3.76 & 2.54 \\
\hline $\mathrm{C} 20: 0$ & 1.22 & 1.53 & 0.62 \\
\hline $\mathrm{C} 22: 0$ & 1.09 & 0.83 & 0.20 \\
\hline $\mathrm{C} 24: 0$ & 0.85 & 0.94 & 0.23 \\
\hline Total Saturated (AGS) & 29.91 & 25.98 & 17.40 \\
\hline$C 15: 1$ cis $(n-5)$ & 0.42 & 0.20 & 0.00 \\
\hline $\mathrm{C} 16: 1$ cis $(n-7)$ & 2.38 & 2.84 & 0.14 \\
\hline $\mathrm{C} 17: 1$ cis $(n-7)$ & 0.34 & 0.00 & 0.05 \\
\hline C18:1 trans $(n-7)$ & 1.09 & 0.49 & 0.62 \\
\hline C18:1 cis (n-9) & 3.57 & 6.01 & 32.40 \\
\hline $\mathrm{C} 20: 1 \mathrm{cis}(n-11)$ & 0.00 & 0.31 & 0.29 \\
\hline Total Monounsaturated & 7.80 & 9.85 & 33.50 \\
\hline $\mathrm{C} 18: 2$ cis $(n-6)$ & 15.97 & 24.67 & 47.56 \\
\hline $\mathrm{C} 18: 3 \operatorname{cis}(n-3)$ & 46.32 & 37.71 & 1.04 \\
\hline$C 20: 2$ cis $(n-6)$ & 0.00 & 0.18 & 0.03 \\
\hline $20: 3$ cis $(n-3)$ & 0.00 & 0.28 & 0.00 \\
\hline $\mathrm{C} 22: 4$ cis $(\mathrm{n}-6)$ & 0.00 & 0.00 & 0.31 \\
\hline$C 22: 5$ cis $(n-3)$ & 0.00 & 1.32 & 0.17 \\
\hline Total Polyunsaturated (PUFA) & 62.29 & 64.16 & 49.11 \\
\hline Total Unsaturated & 70.08 & 74.02 & 82.60 \\
\hline$n-6, \%$ & 15.97 & 24.85 & 47.90 \\
\hline $\mathrm{n}-3, \%$ & 46.32 & 39.31 & 1.21 \\
\hline$n-6 / n-3$ & 0.34 & 0.63 & 39.71 \\
\hline PUFA/AGS & 2.08 & 2.47 & 2.82 \\
\hline
\end{tabular}

Fatty acids were quantified by incorporating internal standard, methyl tricosanoic (C23:0) acid, into each sample during methylation.

Diet was considered the main effect with three levels including OA, OA + VET and OA + SUP. Analysis was conducted using GLM procedure of SAS (Version 9.3, Cary, NC). Residual normality and homogeneity were assessed by Shapiro-Wilk and Levene's tests $(\mathrm{P}>0.05)$. When significance $(\mathrm{P}<0.05)$ was indicated by ANOVA, means separations were performed using the LSMEANS function and individual differences were determined by the Tukey's test $(\mathrm{P}<0.05)$.

\section{RESULTS}

Animals finished with OA + SUP, showed significantly higher $(\mathrm{P}<0.05)$ total lipid content in longissimus lumborum than those finished with $\mathrm{OA}$ 
+ VET, whereas those finished with OA did not show significant differences (Table 2).

The Lignoceric acid (24:0) was the only saturated fatty acid showed variation (Table 2). Animal that received vetch in the diet presented higher content of 24:0 than those who received supplementation. This variation was not sufficient to affect the total amount of saturated fatty acids (SFA) present in longissimus lumborum.

The sum of monounsaturated fatty acids (MUFAs) was not affected by treatments (Table 3). Myristoleic acid content $(14: 1$ cis $)$ was higher $(\mathrm{P}<0.05)$ in the meat of animals received supplementation than in that received only oat pasture. The oleic acid (18:1 cis) levels was higher $(\mathrm{P}<0.05)$ in oat then Oat and Oat + Vetch treatment. The Nervonic acid was higher in Oat + Vetch treatments.
CLA content was lower $(\mathrm{P}<0.05)$ in longissimus lumborum of animals fed with legumes (Table 2). But the deposition of total intramuscular polyunsaturated fatty acids (PUFA), linoleic (18:2 cis), alpha linolenic (18:3 cis n-3), eicosatetraenoic (20:3 cis), arachidonic (20:4 cis) and eicosapentaenoic (20:5 cis) acids was found to be higher $(\mathrm{P}<0.05)$ in oat + vetch fed cattle than in those fed with oat + supplementation.

The animals oat + supplementation fed showed lower PUFA/SFA ratio, n-6, n-3 sum and higher n-6:n-3 ratio (Table 3 ).

\section{DISCUSSION}

It is possible that cornmeal supplementation with high starch content fosters the production of

Table 2 - Fatty acid profile (g/100 g FAME) in longissimus lumborum of steers finished on oat pastures with vetch or cornmeal supplementation.

\begin{tabular}{|c|c|c|c|c|c|}
\hline \multirow[t]{2}{*}{ Fatty acids } & \multicolumn{3}{|c|}{ 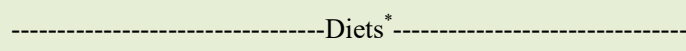 } & \multirow[t]{2}{*}{ Standard error } & \multirow[t]{2}{*}{$\mathrm{P}$ - value } \\
\hline & $\mathrm{OA}$ & $\mathrm{OA}+\mathrm{VET}$ & $\mathrm{OA}+\mathrm{SUP}$ & & \\
\hline Lipids, $\%$ & $1.15^{\mathrm{ab}}$ & $1.02^{\mathrm{b}}$ & $1.25^{\mathrm{a}}$ & 0.06 & 0.0425 \\
\hline $6: 0$ & $\mathrm{X}^{\prime} 0.05$ & 0.05 & 0.04 & 0.01 & 0.6965 \\
\hline $8: 0$ & 0.04 & 0.04 & 0.08 & 0.03 & 0.6503 \\
\hline $10: 0$ & 0.25 & 0.29 & 0.28 & 0.03 & 0,6260 \\
\hline $12: 0$ & 0.24 & 0.19 & 0.21 & 0.04 & 0.6411 \\
\hline $14: 0$ & 2.94 & 2.26 & 2.73 & 0.26 & 0.1849 \\
\hline $15: 0$ & 0.50 & 0.44 & 0.56 & 0.05 & 0.2673 \\
\hline $16: 0$ & 25.2 & 22.9 & 24.6 & 1.30 & 0.4450 \\
\hline $17: 0$ & 1.05 & 0.93 & 1.03 & 0.09 & 0.5931 \\
\hline $18: 0$ & 15.80 & 18.75 & 19.74 & 2.10 & 0.3962 \\
\hline $20: 0$ & 0.14 & 0.14 & 0.15 & 0.01 & 0.8604 \\
\hline $24: 0$ & $0.07^{\mathrm{ab}}$ & $0.09^{\mathrm{a}}$ & $0.05^{\mathrm{b}}$ & 0.01 & 0.0506 \\
\hline $14: 1$ cis $(\mathrm{n}-5)$ & $0.38^{\mathrm{b}}$ & $0.38^{\mathrm{b}}$ & $0.42^{\mathrm{a}}$ & 0.05 & 0.0298 \\
\hline $16: 1$ cis $(n-7)$ & 2.76 & 2.40 & 2.81 & 0.29 & 0.5656 \\
\hline $18: 1$ trans $(\mathrm{n}-9)$ & 0.32 & 0.32 & 0.38 & 0.03 & 0.2535 \\
\hline $18: 1$ cis $(n-9)$ & 36.1 & 34.8 & 36.0 & 0.90 & 0.5448 \\
\hline $18: 1$ trans $(n-7)$ & $2.95^{\mathrm{a}}$ & $1.84^{b}$ & $2.78^{a b}$ & 0.27 & 0.0223 \\
\hline $20: 1 \operatorname{cis}(n-11)$ & 0.13 & 0.12 & 0.13 & 0.01 & 0.7515 \\
\hline $24: 1 \operatorname{cis}(n-9)$ & $0.04^{\mathrm{b}}$ & $0.06^{\mathrm{a}}$ & $0.03^{b}$ & 0.01 & \\
\hline $\mathrm{C} 18: 2$ cis 9, trans 11 (CLA) & $0.57^{\mathrm{a}}$ & $0.40^{\mathrm{b}}$ & $0.59^{\mathrm{a}}$ & 0.04 & 0.0096 \\
\hline $\mathrm{C} 18: 2$ cis $(n-6)$ & $5.43^{\mathrm{ab}}$ & $6.55^{\mathrm{a}}$ & $4.11^{b}$ & 0.47 & 0.0102 \\
\hline C18:3 cis $(n-6)$ & 0.03 & 0.04 & 0.03 & 0.01 & 0.3139 \\
\hline $\mathrm{C} 18: 3$ cis $(n-3)$ & $1.31^{\mathrm{ab}}$ & $1.71^{\mathrm{a}}$ & $0.77^{\mathrm{b}}$ & 0.15 & 0.0026 \\
\hline $20: 3$ cis $(n-6)$ & $0.51^{\mathrm{ab}}$ & $0.74^{\mathrm{a}}$ & $0.36^{\mathrm{b}}$ & 0.07 & 0.0099 \\
\hline $\mathrm{C} 20: 4$ cis $(n-6)$ & $2.23^{\mathrm{ab}}$ & $3.03^{\mathrm{a}}$ & $1.47^{\mathrm{b}}$ & 0.22 & 0.0009 \\
\hline $20: 5 \operatorname{cis}(n-3)$ & $0.76^{\mathrm{b}}$ & $1.35^{\mathrm{a}}$ & $0.47^{b}$ & 0.11 & 0.0002 \\
\hline C22:6 cis $(n-3)$ & 0.16 & 0.26 & 0.13 & 0.04 & 0.0738 \\
\hline
\end{tabular}

$\mathrm{OA}=$ oat pasture $\mathrm{OA}+\mathrm{VET}=$ oat pasture + vetch and $\mathrm{OA}+\mathrm{SUP}=$ oat pasture + supplementation ${ }^{*}$ Means followed by different letters in the same line differ significantly; Tukey test $(\mathrm{P}<0.05)$. 
Table 3 - Total fatty acids profile (g/100 g FAME) in longissimus lumborum of steers finished on oat pastures with vetch or cornmeal supplementation.

\begin{tabular}{|c|c|c|c|c|c|}
\hline & $\mathrm{OA}$ & $\mathrm{OA}+\mathrm{VET}$ & $\mathrm{OA}+\mathrm{SUP}$ & Standard error & P-value \\
\hline Total saturated fatty & 46.3 & 46.1 & 49.5 & 1.20 & 0.1171 \\
\hline Total monounsaturated fatty acids & 39.7 & 37.9 & 39.7 & 1.16 & 0.4426 \\
\hline Total polyunsaturated fatty acids & $13.98^{\mathrm{a}}$ & $15.98^{\mathrm{a}}$ & $10.74^{b}$ & 0.84 & 0.0024 \\
\hline PUFA/SFA ratio ${ }^{* *}$ & $0.30^{\mathrm{a}}$ & $0.35^{\mathrm{a}}$ & $0.22^{b}$ & 0.02 & 0.0035 \\
\hline$n-6$ & $8.20^{\mathrm{ab}}$ & $10.36^{\mathrm{a}}$ & $5.98^{\mathrm{b}}$ & 0.73 & 0.0036 \\
\hline$n-3$ & $2.23^{\mathrm{b}}$ & $3.32^{\mathrm{a}}$ & $1.37^{\mathrm{b}}$ & 0.26 & 0.0004 \\
\hline$n-6: n-3$ ratio & $3.74^{\mathrm{ab}}$ & $3.14^{\mathrm{b}}$ & $4.54^{\mathrm{a}}$ & 0.22 & 0.0022 \\
\hline
\end{tabular}

$\mathrm{OA}=$ oat pasture $\mathrm{OA}+\mathrm{VET}=$ oat pasture + vetch and $\mathrm{OA}+\mathrm{SUP}=$ oat pasture + supplementation. ${ }^{*}$ Means followed by different letters in the same line differ significantly; Tukey test $(\mathrm{P}<0.05)$. ${ }^{* *}$ PUFA: Polyunsaturated fatty acid; SFA: saturated fatty acid.

propionic acid in the rumen and enabled higher amounts of available glucose to the animal, thereby increasing the meat ether extract content (SCOLLAN et al., 2006). SCOLLAN et al. (2001), reported that SFAs such as myristic (14:0), palmitic (16:0), and stearic (18:0) acids are predominant in beef, wherein 18:0 represents approximately $30 \%$ of total SFAs. As well as our results FRUET et al. (2018) reportex low effect of pasture supplementation compared to legume-associated pastures, probably due to the short time of supplementation.

Changes in intramuscular fat occur mainly by the increase of triglycerides during fattening (WOOD et al., 2008). Thus, there is a propensity for a greater accumulation of SFA and MUFA according to the increase of intramuscular fat and proportional decrease of PUFA (CHAIL et al., 2016). The animals of present study didn't show difference for marbling (HIRAI et al., 2014), justifying, in part, the lack of variation in SFA and MUFA.

Animals fed exclusively on pasture have higher PUFA than those fed the concentrate because of the large presence of fatty acids, especially n-3, in pastures compared to that in the concentrate. In addition, long-chain PUFAs in the muscle are associated with phospholipids of cell membranes, which are minimally influenced by nutrition.

The OAT + VET showed higher linoleic, alpha linolenic (ALA), eicosatetraenic, arachidonic and eicosapentaenoic contents in comparation to OAT + SUP. Higher transfer efficiency of PUFA to milk fat from legume-fed cattle compared to grassfed are reported by (KALAČ \& SAMKOVA, 2010). Dewhurst et al. (2003) observed $240 \%$ increase in the proportion of ALA passing through the rumen of animals fed red clover silage, even with a higher biohydrogenation in those fed red clover silage comporated to grass silage (86.1 versus 94.3).

Polyphenols are constantly identified as responsible for limited lipolysis and biohydrogenation. CABIDDU et al. (2010) observed that vetch has higher level of tannic polyphenols than crimson clover. These authors state that tannic phenols had a negative effect on lipolysis and biohydrogenation.

CLA consisted of geometric isomers of linoleic acid and has distinct bioactive characteristics (anticarcinogenic, hypocholesterolemic, antiobesity, and immune-modulatory effects) (KIM et al. 2016). Lower concentrations of CLA were observed in the meat of animals fed OA + VET. MAIA et al. (2007) reported that in relation to MUFAs, PUFAs are more toxic to bacteria involved in the bio-hydrogenation. In ruminants that ingested large quantities of PUFAs, such as high $n-3$ (PUFA) contained in legumes, bio-hydrogenation facilitates the survival of Butyrivibrio fibrisolvens bacteria. High PUFA intake could exceed the bio-hydrogenation capacity of ruminal microorganisms, resulting in higher intestinal absorption of PUFAs, which might explain the lower CLA content of the meat in animals fed with OA + VET.

It was expected that it would have a lower CLA participation in OAT + SUP, but the lower content was in OAT + VET. For NIELSEN et al. (2006) only the presence of grain does not significantly alter the PUFA biohydrogenation in the rumen, CLA and trans-C18: 1 isomers. For this to occur there was a need for the presence of a forage naturally rich in 
starch and linoleic acid, such as corn silage., which wasnot demonstrated in the forages of the present study. VAN DORLAND et al. (2008) observed reduced proportions of CLA, including rumenic acid in milk fat of dairy cows fed with clovers.

The content of vaccenic acid was 2-2.5 times higher than of rumenic acid - CLA, with a strong relationship between them (ELGERSMA et al., 2006). Vaccenic acid is an isomer produced in significant amounts by bio-isomerization and biohydrogenation of linolenic (18:3 n-3) and linoleic (18:2 n-6) acids by the ruminal anaerobic bacteria B. fibrisolvens (GRIINARI \& BAUMAN 1999). The vaccenic acid can be transformed into CLA by the action of $\Delta 9$-desaturase enzyme in the tissues (HAYASHI et. al. 2007) or yield stearic acid by bio-hydrogenation. As well as CLA there was low participation of vaccenic acid in OAT+VET.

Eicosapentaenoic acid (C20:5 n-3, EPA), considered one of the most important 20-carbon fatty acids for human consumption, was formed by the desaturation and elongation of $\alpha$-linolenic acid (SMITH, 2007), which was present in higher levels in leguminous diets, confirmed in the present study.

Total n-3 PUFA was higher in OAT +

VET. Grass and legume contain high proportions of C18:3n3, which is the main $n-3$ series of essential fatty acids (DEWHURST et al. 2006). The literature reported similar responses (SCHMIDT et al., 2013; WRIGHT et al., 2015). The lower linoleic acid content of legumes compared to grasses may explain changes in rumen biohydrogenation in grazing steers (WRIGHT et al., 2015). This reduction in linolenic acid biohydrogenation increased the flow of linolenic acid and decreases the flow of stearic and vaccine acids to the duodenum (LEE et al., 2006).

The n-3 fatty acids might help to prevent or treat a variety of diseases, including heart disease, cancer, arthritis, depression, and Alzheimer's disease (KIM et al., 2016). The n-6 have important physiological functions as cell membrane constituents, in regulation of blood viscosity, permeability of blood vessels, maintaining blood pressure, inflammation, and platelet function (KIM et al. 2016). Per the nutritional recommendation by the Department of Health (1994), bovine meat is considered a healthy food for humans if the n-6:n-3 ratio does not exceed the limit of 4 . In the present study, this ratio was greater than 4 in animals fed with OA + SUP, which was significantly higher $(\mathrm{P}<0.05)$ than those finished with OA + VET, which averaged approximately at 3 .

\section{CONCLUSION}

Steers finished in oat mixture with vetch showed healthier intramuscular fat than did those finished with corn meal supplementation; importantly, the higher the amount of PUFAs, the better n-6:n-3 ratio. Animals receiving vetch showed relatively low amounts of CLA.

\section{ACKNOWLEDGEMENTS}

This research was supported by National Council for Scientific and Technological Development of Brazil, through the productivity grant granted to Menezes and financial resources. Process: 471668/2011-7. And was financed in part by the Coordenação de Aperfeiçoamento de Pessoal de Nível Superior (CAPES), Brasil - Finance code 001

\section{BIOETHICS AND BIOSSECURITY COMMITTEE APPROVAL}

The animal rearing and management activities were approved by the animal research ethics committee - CEUA, of the Universidade Tecnológica Federal do Paraná (UTFPR), filed under number 2014-009.

\section{DECLARATION OF CONFLICT OF INTERESTS}

The authors declare no conflict of interest. The founding sponsors had no role in the design of the study; in the collection, analyses, or interpretation of data; in the writing of the manuscript, and in the decision to publish the results.

\section{AUTHORS' CONTRIBUTIONS}

All authors contributed equally for the conception and writing of the manuscript. All authors critically revised the manuscript and approved of the final version.

\section{REFERENCES}

Bligh EG, Dyer WJ. A rapid method of total lipid extraction and purification. Canadian Journal Biochemistry and Physiology v.37, n.8, p.911- 917, 1959. Available from: $<$ https://www.nrcresearchpress.com/doi/abs/10.1139/y59-099\#. XoSNX25FzIV>. Accessed: Apr. 01, 2020. doi: doi.org/10.1139/ y59-099.

CABIDDU A. et al. The influence of plant polyphenols on lipolysis and biohydrogenation in dried forages at different phenological stages: in vitro study. Journal of the Science of Food and Agriculture, v.90, p.829-835, 2010. Available from: <https:// onlinelibrary.wiley.com/doi/epdf/10.1002/jsfa.3892>. Accessed: Apr. 11, 2018. doi: 10.1002/jsfa.3892.

CAMPBELL, N.A.; ARNOLD, G. W. The visual assessment of pasture yield. Australian Journal of Experimental Agriculture, v.13, p.253-267, 1973. Available from: <https://www.publish.csiro.au/ an/EA9730263>. Accessed: Apr. 11, 2018. doi: 10.1071/EA9730263. 
CHAIL, A. et al. Legume finishing provides beef with positive human dietary fatty acid ratios and consumer preference comparable with grain-finished beef. Journal of Animal Science, v.94, p.2184-2197, 2016. Available from: $<$ https://academic.oup. com/jas/article-abstract/94/5/2184/4701754>. Accessed: Oct. 10, 2017. doi: $10.2527 /$ jas.2015-0241.

DEPARTMENT OF HEALTH. Nutritional aspects of cardiovascular disease. Health and Social Subjects, 46, 37-46, 1994.

DEWHURST R.J. et al. Comparison of grass and legume silages for milk production. 2. In vivo and in sacco evaluations of rumen function. Journal of Dairy Science, v.86, p.2612-2621, 2003. Available from: <https://www.sciencedirect.com/science/article/ pii/S0022030203738569>. Accessed: Apri. 01, 2018. doi: 10.3168/ jds.S0022-0302(03)73856-9.

DEWHURST R.J. et al. Increasing the concentrations of beneficial polyunsaturated fatty acids in milk produced by dairy cows in highforage systems. Animal Feed Science and Technology, v.131, p.168-206, 2006. Available from: <https://www.sciencedirect. com/science/article/pii/S0377840106002604>. Accessed: Oct. 17, 2018. doi: 10.1016/j.anifeedsci.2006.04.016.

ELGERSMA A. et al. Modifying milk composition through forage. Animal Feed Science and Technology., 131, 207-225, 2006. Available from: $<\mathrm{https}: / / \mathrm{www} . s c i e n c e d i r e c t . c o m / s c i e n c e /$ article/pii/S0377840106002616>. Accessed: Feb. 04, 2018. doi: 10.1016/j.anifeedsci.2006.06.012.

FRUET, APB., et al. Effects of feeding legume-grass pasture and different concentrate levels on fatty acid profile, volatile compounds, and off-flavor of the M. longissimus thoracis. Meat Science 140, 112-118, 2018. Available from: <https://www. sciencedirect.com/science/article/pii/S0309174017312330> Accessed: Feb. 04, 2018. doi: 10.1016/j.meatsci.2018.03.008.

GARCIA, P.T. et al. Beef lipids in relation to animal breed and nutrition in Argentina. Meat Science, v.79, p.500-508, 2008. Available from: <https://www.sciencedirect.com/science/article/ abs/pii/S0309174007003233>. Accessed: Oct. 01, 2018. 10.1016/j. meatsci.2007.10.019

GRIINARI, J.M.; BAUMAN, D.E. Biosynthesis of conjugated linoleic acid and its incorporation into meat and milk of ruminants. (Eds. Yurawecz MP, Mossoba MM, Kramer JKG, Pariza MW, Nelson GJ Advances in Conjugated Linoleic Acid Research. p. 180-200. (AOCS Press, Champaign,IL), 1999.

HARTMAN L.; LAGO R.C.A. Rapid preparation of fatty acid methyl ester from lipids. Laboratory Practice, v.22, p.475-476, 1973. Available from: $<$ http://www.nutriphill.com.br/analise_ital. pdf $>$. Accessed, Jan. 28, 2018.

HAYASHI, A.A. et al. Conjugated linoleic acid (CLA) effects on pups growth, milk composition and lipogenic enzymes in lactating rats. Journal Dairy Research, v.74, p.160-166, 2007. Available from: $<$ https://www.cambridge.org/core/journals/journal-of-dairyresearch/article/conjugated-linoleic-acid-cla-effects-on-pupsgrowth-milk-composition-and-lipogenic-enzymes-in-lactating-rat s/7F8698A833EAE62EE3726D87D965639F > . Accessed: Oct. 18, 2018. doi: $10.1017 / \mathrm{S} 002202990600224 \mathrm{X}$

HIRAI, M.M.G. et al. Finishing steers on oat pasture intercropped with legumes or receiving energetic supplementation. Arquivo
Brasileiro de Medicina Veterinária e Zootecnia, v.67, p.11411149, 2015. Available from: <http://www.scielo.br/pdf/abmvz/ v67n4/0102-0935-abmvz-67-04-01141.pdf $>$. Accessed: Apr. 11, 2018. doi: $10.1590 / 1678-4162-7122$.

HIRAI, M.M.G. et al. Carcass traits and meat quality of steers finished on pasture of white oat. Semina: Ciências Agrárias, v.35, p.2617-2628, 2014. Available from: <http://www.uel.br/seer/ index.php/semagrarias/article/view/14429>. Accessed: Apr. 18, 2018. Doi: 10.5433/1679-0359.2014v35n4Suplp2617.

KALAČ, P.; SAMKOVÁ, E. The effects of feeding various forages on fatty acid composition of bovine milk fat: A review. Czech Journal of Animal Science, v.55, p.521-537, 2010. Available from: <https://pdfs.semanticscholar.org/08f5/ c5712fe0a55694869e9ac038ddb2847253de.pdf $>$. Accessed: Oct. 23, 2017.

KIM, J.H. et al. Conjugated linoleic acid: Potential health benefits as a functional food ingredient. Annual Review of Food Science and Technology, v.7, p.221-244, 2016. Available from: <https://www.annualreviews.org/doi/abs/10.1146/annurevfood-041715-033028>. Accessed: Feb. 04, 2018. doi: 10.1146/ annurev-food-041715-033028.

LEE, M.R. et al. Effects of high-sugar ryegrass silage and mixtures with red clover silage on ruminant digestion. 2. Lipids. Journal of Animal Science, v.84, p.3061-3070, 2006. Available from: $<$ https:// academic.oup.com/jas/article-abstract/84/11/3061/4779115. Accessed: Jan. 28, 2018. doi: 10.2527/jas.2005-736>.

LISBINSKI, E. et al. Performance and ingestive behavior of steers on integrated system using legume and/or energy supplementation. Tropical animal health and production, v.51, p.205-211, 2019. Available from: $<$ https://link.springer.com/article/10.1007/s11250018-1678-4>. Accessed: Oct. 29, 2019. doi: 10.1007/s11250-018$1678-4$.

MAIA, M.R. et al. Metabolism of polyunsaturated fatty acids and their toxicity to the microflora of the rumen. Antonie Van Leeuwenhoek, v.91, p.303-314, 2007. Available from: <https:// link.springer.com/article/10.1007/s10482-006-9118-2>. Accessed: Oct. 29, 2019. doi: 10.1007/s10482-006-9118-2.

MOORE, J. E., et al. Effects of supplementation on voluntary forage intake, diet digestibility, and animal performance. Journal of Animal Science, v.77.suppl_2, p.122-135, 1999. Available from: $\quad<$ https://academic.oup.com/jas/articleabstract/77/suppl_2/122/4653431>. Accessed, Jan. 28, 2018. doi: $10.2527 / 1999.77$ suppl_2122x.

MOTT, G.O.; LUCAS, H.L. The design, conduct, and interpretation of grazing trials in cultivated and improved pastures. Proceedings of the international grassland congress, 1952 (pp. 1380-1385). USA: Pennsylvania, 1952.

MULVIHILL, B. Ruminant meat as a source of conjugated linoleic acid (CLA). British Nutrition Foundation Nutrition Bulletin, v.26, p.295-299, 2001 Available from: https://doi. org/10.1046/j.1467-3010.2001.00179.x. Accessed: Jan. 28, 2020. doi: 10.1046/j.1467-3010.2001.00179.x.

NIELSEN, T.S. et al. Effect of silage type and concentrate level on conjugated linoleic acids, trans-C18:1 isomers and fat content in milk from dairy cows. Reproduction Nutrition Development., v.46, p.699-712, 2006. Available from: <https://rnd.edpsciences. 
org/articles/rnd/abs/2006/07/r6608/r6608.html>. Accessed: Apr. 10, 2018. doi: $10.1051 /$ rnd:2006044.

SCHMIDT, J.R. et al. Effects of summer forage species grazed during finishing on animal performance, carcass quality, and meat quality. Journal of Animal Science, v.91, p.4451-4461, 2013. Available from: <https://academic.oup.com/jas/articleabstract/91/9/4451/4717403>. Accessed: Apr. 10, 2018. doi: $10.2527 /$ jas.2012-5405.

SCOLLAN, N.D. et al. Manipulating the fatty acid composition of muscle and adipose tissue in beef cattle. British Journal Nutrition, v.85, p.115-124, 2001. Available from: <https://www. cambridge.org/core/journals/british-journal-of-nutrition/article/ manipulating-the-fatty-acid-composition-of-muscle-and-adiposetissue-in-beef-cattle/6A0364E7164C00E111404433B7AC0D99>. Accessed: Apr. 11, 2018. doi: 10.1079/BJN2000223.

SCOLLAN, N. et al. Innovations in beef production systems that enhance the nutritional and health value of beef lipids and their relationship with meat quality. Meat Science, v.74, p.17-33, 2006. Available: <https://www.sciencedirect.com/science/article/abs/pii/ S0309174006001409>. Accessed: Apr. 10, 2018. doi: 10.1016/j. meatsci.2006.05.002.

SMITH, W.L. Nutritionally essential fatty acids and biologically indispensable cyclooxygenases. Trends Biochemistry Science, v.1, p.27-37, 2007. Available from: <https://www.sciencedirect. com/science/article/abs/pii/S0968000407002897>. Accessed: Jan. 28, 2018. doi: 10.1016/j.tibs.2007.09.013.

VAN DORLAND, H.A. et al. Comparative potential of white and red clover to modify the milk fatty acid profile of cows fed ryegrass-based diets from zero-grazing and silage systems. Journal of the Science of Food and Agriculture, v.88, p.7785, 2008. Available from: <https://onlinelibrary.wiley.com/doi/ full/10.1002/jsfa.3024? casa token=H607VP-f3qIAAAAA\%3A6o sK4xo7WFaMOVFzVAzNX̄XB7vQXCcQcBIygtDay0YSIclJheT
Vrys4gqs0FcLTavZ_QfNhnj4Quhjudv>. Accessed: Jan, 28, 2018. doi: $10.1002 /$ jsfa. 3024 .

VAN SOEST, P.J. Nutritional ecology of the ruminant. 2.ed. (Cornell University, Ithaca. N.Y., USA), 1994. Available from: $<$ https://books.google.com.br/books?hl=pt-PT\&lr=\&id=TlluDwA AQBAJ\&oi $=$ fnd \&pg $=$ PP $1 \& d q=$ Nutritional + ecology + of + the + rum inant\&ots $=$ lnCeHhnSjz\&sig $=$ jIlkCe8dWOHK9tibB6ZIgwwpDG8 $\&$ redir_esc $=\mathrm{y} \# \mathrm{v}=$ onepage $\& \mathrm{q}=$ Nutritional $\% 20$ ecology $\% 20$ of $\% 20$ the $\% 20$ ruminant\&f=false $>$. Accessed: Jan. 28, 2018

VARELA, A. et al. Effect of pasture finishing on the meat characteristics and intramuscular fatty acid profile of steers of the Rubia Gallega breed. Meat Science, v.67, p.515-522, 2004. Available: <https://www.sciencedirect.com/science/article/abs/pii/ S0309174003003498>. Accessed: Oct. 10, 2018. doi: 10.1016/j. meatsci.2003.12.005.

WAGHORN, G.C.; CLARK, D.A. Feeding value of pastures for ruminants. New Zealand Veterinarian Journal, v.52, p.320331, 2004. Available from: <https://www.tandfonline.com/doi/ful $1 / 10.1080 / 00480169.2004 .36448$ ? scroll $=$ top\&needAccess $=$ true $>$. Accessed: Oct, 10, 2018. doi: 10.1080/00480169.2004.36448.

WOOD, J.D. et al. Effects of fatty acids on meat quality: a review. Meat Science, v.66, p.21-32, 2003. Available from: $<$ https://www. sciencedirect.com/science/article/abs/pii/S0309174003000226>. Accessed: Apr. 11, 2018. doi: 10.1016/S0309-1740(03)00022-6.

WOOD, J.D. et al. Fat deposition, fatty acid composition and meat quality: A review. Meat Science. v.78, p.343-358, 2008. Available from: $<$ https:// www.sciencedirect.com/science/article/abs/pii/S0309174007002525>. Accessed: Apr. 11, 2018. doi: 10.1016/j.meatsci.2007.07.019.

WRIGHT, A. M. et al. Effect of forage type with or without corn supplementation on animal performance, beef fatty acid composition, and palatability. Journal of Animal Science, v.93, p.5047-5058, 2015. Available from: $\quad<$ https://academic.oup.com/jas/article/93/10/5047/4701840>. Accessed: Apr. 11, 2018. doi: 10.2527/jas.2015-8939. 